\title{
A CITATION ANALYSIS OF ECCLESIASTES SCHOLARSHIP: \\ A TEST CASE USING CITATION ANALYSIS IN BIBLICAL STUDIES
}

Submitted for the

Fourth Annual International Conference on Information and Religion

Timothy Senapatiratne

t-senapatiratne@bethel.edu

May 2014 


\section{INTRODUCTION}

Theological libraries have a long history in librarianship, but very little work has been done in trying to understand the nature of the materials that theological libraries collect. For example, within the social science subset of Journal Citation Reports, no journals were retrieved using the search terms "Bible," or "biblical" and only one result was produced using the search term "theology." As theological libraries (and libraries with large theology and religion collections) feel financial pressures to maintain a relevant and quality collection while justifying each and every purchase, a better understanding of the citation patterns within the broad fields of theology, church history, religion and biblical studies is needed. By doing so it is hoped that the gathered information would help librarians with collection development by giving librarians knowledge about what materials are actually being used by scholars. Thus, this study has examined a small sub-set of this biblical literature in order to better understand the citation patterns (if any) are evident in this literature.

\section{Statement of Problem and Sub-Problems}

This study investigated the authorial citing pattern of scholarly biblical literature covering Ecclesiastes. Specifically, it investigated what types of material (books, journals, and essays), authors and journals were cited the most during the ten years of 2003 to 2012. In order to do this, the corpus of related scholarly journal literature on Ecclesiastes over the last ten years was gathered. Next, each of these articles was examined and each of their citations was documented 
for format and authorship. Finally, these results were collated to determine what types of material and which authors were most cited.

\section{Statement of the Purpose of the Research}

The purpose of this study was to better understand what authors, journals, and generally what types of material (books, journals, and essays) are being cited the most in scholarly biblical literature to aid librarians in collection development. Because this type of study has never been done before, it is also hoped that this initial work might also be the starting place for better understanding research patterns in biblical studies. For purposes of manageability this study examined the academic journal literature produced on the biblical book of Ecclesiastes in the last ten years.

\section{Research Questions}

R1. What types or formats of materials are cited in peer-reviewed articles about Ecclesiastes in the last ten years?

R2. Who are the most cited authors in the articles in this study?

R3. Which journals are the most-cited in the articles in this study?

$\mathrm{R} 4$. What is the average age of the sources used in each article?

\section{Definitions}

Biblical Studies: The term biblical studies is used in this study as an umbrella term that includes any of the scholarly critical approaches to the collection of ancient documents commonly called the Bible. The Society of Biblical Literature, the "largest and oldest scholarly 
community" established for biblical studies, describes their society on their Web site as being "devoted to the critical investigation of the Bible from a variety of academic disciplines" (2011).

Scholar: For the purposes of this project, a scholar is either a person who has an advanced research degree in some area of biblical studies (generally a Ph.D.), has had a publication accepted in a biblical studies peer-reviewed journal, or both.

Scholarly Journal Article: For the purposes of this project, a scholarly journal article is an article published in an academic journal that uses a double-blind peer-review editorial acceptance process.

\section{Delimitations of the Study}

Journal Articles: This study was specifically limited to the sources used in journal articles. It did not include a survey of books or essays published in books. Journal articles were chosen as the focus of this study because of the comparability with citations studies that have been done in the sciences. While this has limited the scope of the study, the limit creates a specific, although arbitrary, boundary.

ATLA Religion Database: The search for journal articles was limited to those appearing in the ATLA Religion Database. This limit was put in place to make the study manageable, but it also functioned with the assumption that the ATLA Religion Database is the most comprehensive and most used source for biblical scholars to find secondary source material (see Critique of Study below for some evaluation of this decision). It is acknowledged that there may possibly be some outliers in databases like JSTOR, Old Testament Abstracts and the Catholic Periodical and Literature Index. While the 
inclusion of these data sources would have allowed for greater completeness, their exclusion made the project manageable. Jack Ammerman (2006) while claiming to be "descriptive, not evaluative" (p. 169), does, in fact, present a compelling argument that suggests the ATLA Religion Database is representative of the scholarship of biblical studies.

Biblical Studies: The journal articles surveyed were limited to those on topics under the biblical studies umbrella. Specifically, theological approaches (articles specifically concerned with the application of biblical material) were not included nor were articles that investigated the history of Ecclesiastes interpretation.

\section{Assumptions}

It was assumed during the research for this essay that the author citing the source was familiar with the source (Smith, 1981, p. 87), but unlike Smith's suggestion, the essay's method did not rely on the assumption that the cited material was the best material available on the cited topic. In fact, this study's conclusions suggest that sometimes the best material was not used. Similarly, this study did not need to assume that a citation implies merit, since awareness of the source is at the heart of the research question, not quality (contra Smith, 1981, p. 87). Further, it was assumed that the ATLA Religion Database is adequately representative of the biblical studies corpus and that it was accurately indexed so that relevant articles are able to be retrieved (although this assumption is questioned in the Critique of Study section). It was also assumed that the division between biblical studies and other related fields like systematic theology is sufficiently clear that a determination between these disciplines could be made and applied consistently by the researcher. 


\section{Importance of the Study}

The major benefit of this project was to help theological librarians (and librarians of biblical studies collections) better understand what kinds of collections they need to maintain for the study of particular books of the Bible. Since theological libraries spend thousands of dollars each year purchasing new commentaries on biblical books as well as biblical studies journals, this study offers some ideas that help to inform the collection needs of these new materials.

\section{LITERATURE REVIEW}

\section{Citation Analysis in Biblical Studies}

No previous citation analysis of a biblical studies topic can be found in the scholarly literature. In fact, a keyword search of the ATLA Religion Database for "citation analysis" produces only 20 articles of which four are a review of one book on inter-textual citations of ancient documents. Twelve of the other citations are also for inter-textual citations between other ancient documents. Only three of the results are directly about citation analysis of scholarly literature in the sense used by librarians. Of these three articles, none are about biblical studies. These articles were published in 2006, 1995, and 1983. This averages to only one article per decade in the ATLA Religion Database that has anything to do with citation analysis.

\section{Citation Analysis}

It is fairly well agreed in library science literature that citation analysis is "uniquely successful for studying the impact, structures, and networks of scientific communities because of 
its relative unobtrusiveness, objectivity, reliability, and low cost" (Zhao \& Strotmann, 2011, p. 564). Similarly, Hoffmann and Doucette (2012) say that citation analysis allows a researcher a better ability to "understand scholarly communication trends within a discipline" (p. 321). More simply, Smith (1981) suggests that citation analysis is a way of understanding how the "cited document and the citing document" relate to each other (p. 84). Rethlefsen (2007) points out that citation analysis shows "actual research needs as reflected by the items referenced" of the authors of particular pieces of research (p. 261). Hoffmann and Doucette (2012) state that user studies are a good way to determine citation trends and also the type of materials that are being used within a particular community, which, in turn, helps librarians with many services including collection development (p. 322). Their concern is that often the methods being used for citation analysis are not explicitly given so that the study cannot be replicated or compared to other similar studies (Hoffmann \& Doucette, 2012, p.322). Their argument is that any citation analysis should be "deliberate about methodological choices, be selective about what is analyzed and presented, and clearly describe their decisions and rationale" (Hoffmann \& Doucette, 2012, p.327).

While the use of citation analysis is basically non-existent in the discipline of biblical studies, a few citation analyses have been done in other humanities based disciplines, including a growing number of studies done comparing the use of sources in various kinds of theses. Often these studies compare the sources used in the thesis with the actual collection of a particular academic library. For example, Kellsey and Knievel (2012, p. 569) use citation analysis to determine if their humanities collection was adequate for the faculty doing research using their library. Kellsey and Knieval (2005, p. 149) determine, however, that the humanities cannot be looked at as a whole, but must be analyzed within each discipline. That is to say, theses on 
religion and theses about the arts demonstrate different citation patterns (Kellsey and Knieval, 2005, p. 149). This furthers the argument that citation analysis of biblical studies materials should be done separately; separate even from those studies that have looked at religion or theology. In fact, Kellsey and Knieval (2005) acknowledge the need for specific biblical studies work when they write, "The wide variety of subfields in religion (from theology and biblical studies to Islam, Buddhism, etc.) makes this another field in which further research would be fruitful" (p.164). Ashman (2009, p. 126), in an examination of citation analysis studies, finds that the overwhelming majority of citation studies (seventy percent) do not focus on one academic discipline, but rather are interdisciplinary. This fact further illustrates the need for subject specific citation analysis.

\section{Suitability of Ecclesiastes as a Test Case}

Ecclesiastes presents a rather unique test case for doing an examination of citation patterns in biblical studies. This is particularly true because the book is often studied by itself in exclusion with other biblical books that might add complexity to any citation analysis. The trouble of relating Ecclesiastes to other written works, either within the Bible or outside, is best illustrated by Murphy's (2002) somewhat exasperated declaration that Ecclesiastes is "sui generis" (p. 50). At the same time, the book of Ecclesiastes continues to attract the attention of some of the best scholarly minds involved in Hebrew Bible scholarly study.

The current state of Ecclesiastes scholarship centers around three intersecting axes. These are genre and structure, authorship and dating, and finally, interpretation and meaning. Murphy's (2002) claim of sui generis notwithstanding, many different approaches to the genre and structure have been proposed, including Egyptian testament (Longman, 1998); dialogue (Perry, 
1993); philosophical treatise (Fox, 1999) and collection of worldly wisdom (Whybray, 1981).

Similarly, while the pervasive belief among scholars is that Ecclesiastes was written sometime in the $5^{\text {th }}$ or $4^{\text {th }}$ centuries BCE, the debate rages as to what specific time and, more importantly, what cultural influence are evident within the book. For example, Murphy $(2002,1992)$ argues that the book is relatively late and demonstrates a strong Hellenistic influence. Seow (1997) counters that the book has no Hellenistic influence, but rather shows a strong affinity to the Persian literature of the earlier $5^{\text {th }}$ Century. Fox (1999) suggests a proto-Epicurian influence, while Dahood's (1952) minority position is that the book was strongly influenced by Phoenician sources. Interpretation suggestions range from traditional Hebrew skepticism (Fox, 1999; Murphy 2002) to polemical writing against the Persians (Seow, 1997).

While these issues obviously do not have to be solved in this study, they do illustrate the variety of opinions on Ecclesiastes and why Ecclesiastes presents a good test case for citation analysis. Since each of the proposed theories either builds on or critiques the other theories the interrelatedness (or lack of interrelatedness) of the theories is informative. Thus, the nonhomogenous nature of scholarship on this small and fairly easily definable sub-set of biblical scholarship produces interesting results for an initial foray into biblical studies scholarship using citation analysis.

\section{METHODOLOGY}

For this particular citation analysis the method used was relatively straight-forward. This included establishing a data set (of journal articles), gathering the citations in each article and 
then grouping or counting these citations based on the research questions. This straight-forward approach made the research easy to conduct and allowed for clear data conclusions.

\section{Article Identification}

The sample set of Ecclesiastes articles was gathered by using the ATLA Religion Database. Limits for dates (2003 to 2012) and material type (academic journal) were used. To eliminate articles that did not fit into the biblical studies discipline only articles subject indexed with either a subject of "Bible. Ecclesiastes - Criticism, Interpretation," "Bible. Ecclesiastes Criticism, Literary," or "Bible. Ecclesiastes - Criticism, Textual," were used. Those articles within this set that clearly still did not fit the biblical studies discipline were eliminated. Finally, any articles written primarily in a language other than English were not used.

\section{Citation Gathering}

Once the articles were identified, each source used in each article was gathered and added to a spreadsheet. Since the number of times a source was used within an article was not relevant to this study, if an article had a bibliography or reference list, these data sources were used to collect this information. On an Excel spreadsheet, the following information was compiled: citing document, cited material type (journal article, monograph, essay [chapter in book or signed encyclopedia article], primary source or website), cited author, and cited journal (if a journal article). Monographs that were commentaries were identified as such. The cited documents publication date was also collected. The cited document's title and other bibliographic information were also collected for possible future use. While perhaps a weakness 
of the study, citations of works that were clearly reference works (dictionaries, lexicons, etc.) were counted as citations, but not included in date ranges.

When the data were gathered it was collated into four lists. One list identified the types of materials cited and number of times each format was used. Another list identified all the authors cited and the number of times they were cited and a third list identified each journal cited and how many times each was cited. The fourth list noted the date of each source used. These dates were averaged and then the date of the citing article was subtracted from the average to establish the average age of the cited material.

\section{RESULTS}

\section{Data Collection}

Using the ATLA Religion database and the search parameters listed above, 46 articles were found (see data bibliography). Of the 46 articles, 10 were eliminated because while they were indexed in the database under the established criteria there were compelling reasons to eliminate them. Bøggild (2012) was eliminated since the topic of the article was about the theologian Kierkegaard and not Ecclesiastes. Apparently the indexer included Ecclesiastes as a subject heading because there was a single reference to Ecclesiastes in the article. Gómez (2012), Klein-Braslavy (2005) and Drewes (2005) were eliminated because their articles focused on interpretations of Ecclesiastes as their primary task and not on the text of Ecclesiastes. For example, Gomez (2012) focused on Jewish Medieval Era commentaries on Ecclesiastes. Sanders (2005) might have been included in the study, but was eventually eliminated since his article was more of a survey of wisdom literature than an exposition of the Ecclesiastes text. Vogel (2005) 
was eliminated since he used Ecclesiastes to interpret Genesis and did not interact with any Ecclesiastes scholarship. Treier (2008) was eliminated because this article focused on biblical hermeneutics and simply used a text in Ecclesiastes as a test case for the author's argument. Similarly, Okello (2004) was eliminated since the topic of his article was about the use of logic in the Bible and not Ecclesiastes. Helsel (2007) was removed from the list because the author was using Ecclesiastes for counselling purposes and not interpreting the text. Finally, Whitacre (2007) was eliminated because it was not a journal article, but a book review of an Ecclesiastes commentary. Clearly this citation was indexed incorrectly.

Thus, the working sample was reduced to 36 articles. One of the articles, Rosenberg (2008), did not actually have any footnotes. Because of this, unless noted the Rosenberg article was not be factored into the data (especially those with averages). Another article, Polish (2008) had only one reference which was a primary source document dated to 1959 . This article was included in the data to maintain the integrity of the data.

\section{Research Questions Results}

Before presenting answers to the research questions it is important to note an unexpected development in the data collection that affected the results and also impacts the reporting of the results. Of the 36 articles (not including Rosenberg [see above]), 6 (or 16.6\%) of the articles were written by one author (Aron Pinker). All of Pinker's articles involved the very technical process of trying to establish particular Hebrew readings (with English translations) of Ecclesiastes. Pinker's methods are somewhat unorthodox (for the discipline) because he tends to favor older commentaries and reference materials for his sources, rather than thoroughly engaging in more current source materials. Thus, some of the data must be shown in two forms: 
with Pinker's articles included and also without Pinker's articles. This was to make sure that Pinker's work and methods dis not unduly skew the data.

\section{R1. What types or formats of materials are cited in peer-reviewed articles about Ecclesiastes in the last ten years?}

The first research question this project examined was a question of formats. For clarity, the format types were kept to a minimum. All material that was found in any serial publication was considered an "article;" this included annuals. Single chapters in collected volumes (that were not serials) or signed encyclopedia articles were considered "essays." Book length material was classified into three simple categories. The first category considered for book length material was whether the book was a commentary. A commentary was defined as a book that treated the entirety of a biblical book of the Bible with the intent of discussing every verse or chapter in the biblical book. Books that explored thematic or literary approaches to biblical books without intending to completely deal with the biblical book were considered monographs. Works that were clearly being used as primary sources were noted as such (although if introductions or others parts of the book were referenced they were marked as monographs). Having established these criteria, determining the types of materials used in the sample set was relatively easy, simply needing a count.

Within the 36 articles, 1134 resources were cited (this includes duplicates from separate articles). This averages to 31.5 sources per article. Removing Polish's (2008) one citation, the average citations per article goes up to 32.4. 
Of the 1134 resources, 208 or $18.3 \%^{1}$ of the resources used were articles. Commentaries comprised 264 of the resources or $23.3 \%$ of the resources. There were 192 essays which made up $16.9 \%$ of the sources. The largest group of resources was the 413 monographs, which made up $36.4 \%$ of the citations. There were 33 primary sources $(2.9 \%), 15$ reference works and 9 websites.

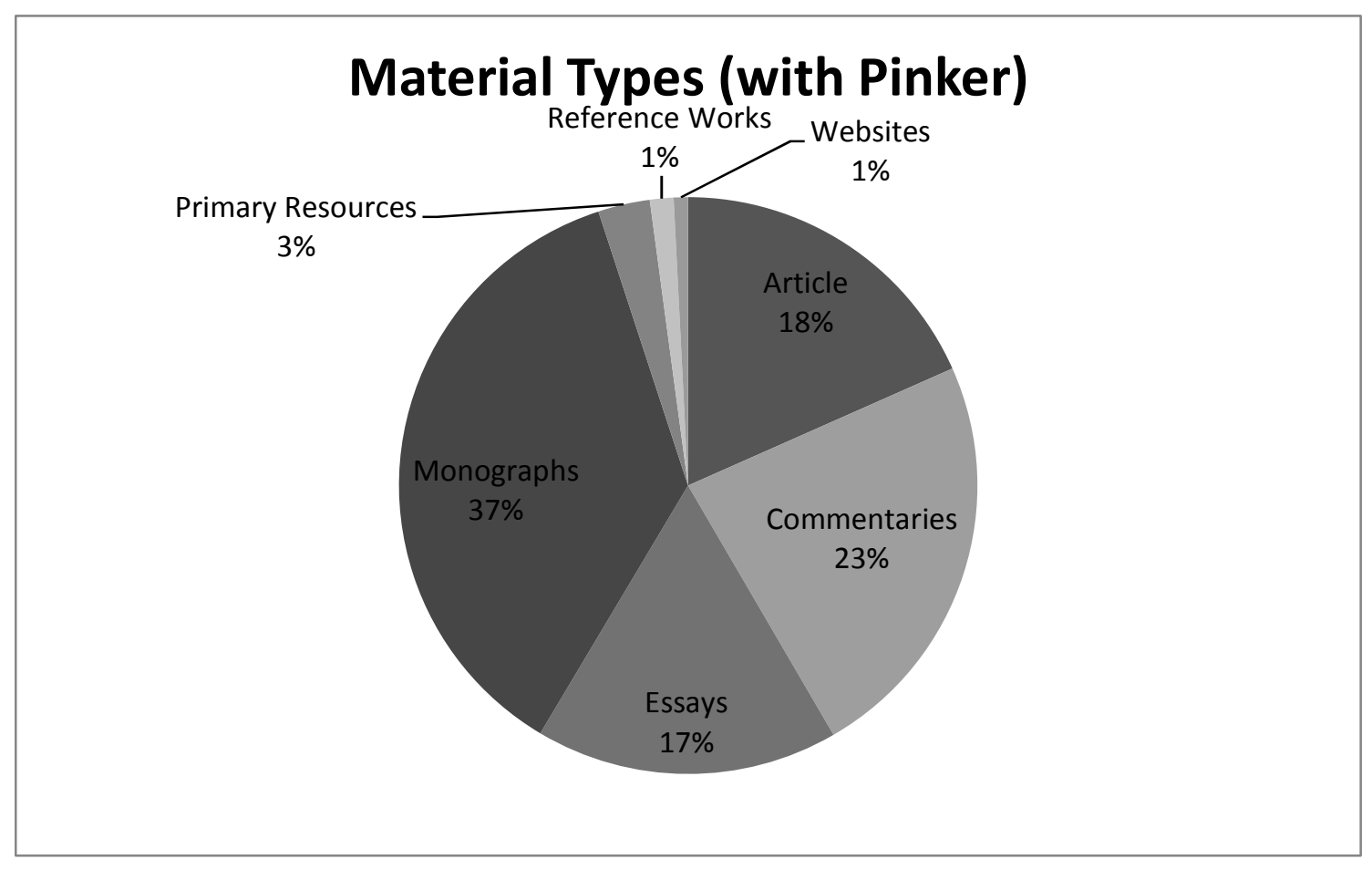

Figure 1: Material Types (with Pinker)

Not including Pinker, 176 of the 913 resources were articles (19.7\%), 169 were commentaries (18.5\%), 165 were essays (18.1\%), 348 were monographs (38.2\%), 31 were primary sources (3.4\%), there were 14 reference works used and 9 websites. Thus, Pinker's articles did not skew the material types data.

\footnotetext{
${ }^{1}$ Percentages do not equal $100 \%$ because of rounding in this section.
} 


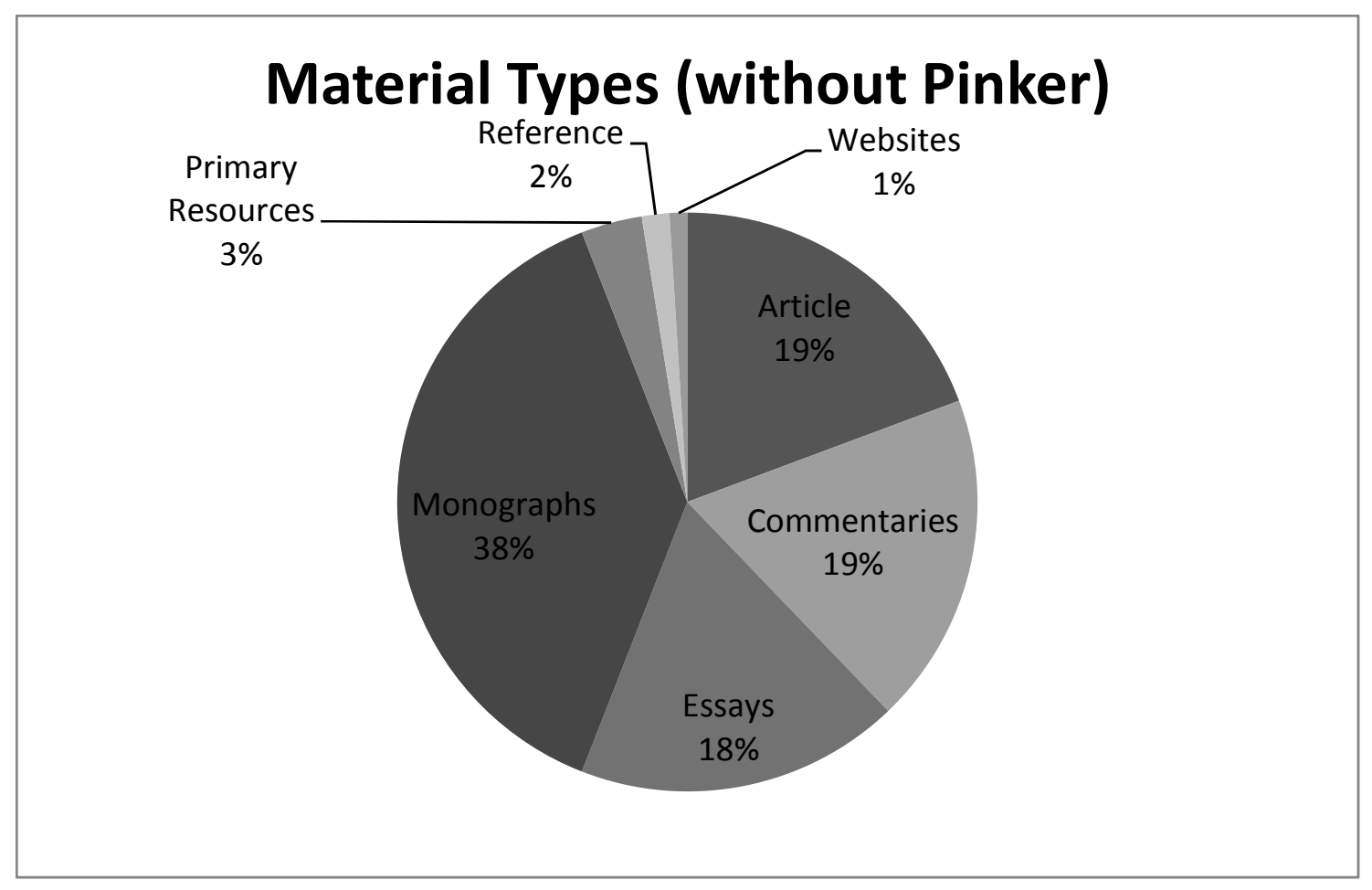

Figure 2: Material Types (without Pinker)

In both cases monographs were used about twice as often as any other resource.

Interestingly, book length resources (commentaries and monographs) account for about $60 \%$ of the resources used. Over $80 \%$ of the resources used were not articles.

\section{R2. Who are the most cited authors in the articles in this study?}

Determining the most cited authors was again simply a matter of counting sources. At least 38 different authors were cited at least 5 times. M. V. Fox was cited 54 times in at least 25 different articles (or over $69 \%$ of the articles). J. L. Crenshaw was cited 46 times in at least 26 (72\% of articles) of the articles (he did cite himself 11 times). C. L. Seow was cited 30 times in 20 articles (56\% of the articles). R. N. Whybray (18 times/10 articles), G. S. Ogden (17 times/11 articles), T. Longman (17 times/16 articles), R. Gordis (17 times/15 articles), R. E. Murphy (14 
times/11 articles) and N. Lohfink (14 times/11 articles) were other highly cited authors.

Interestingly, of the 36 articles only one (Crenshaw, 2007) cites another in the study group!

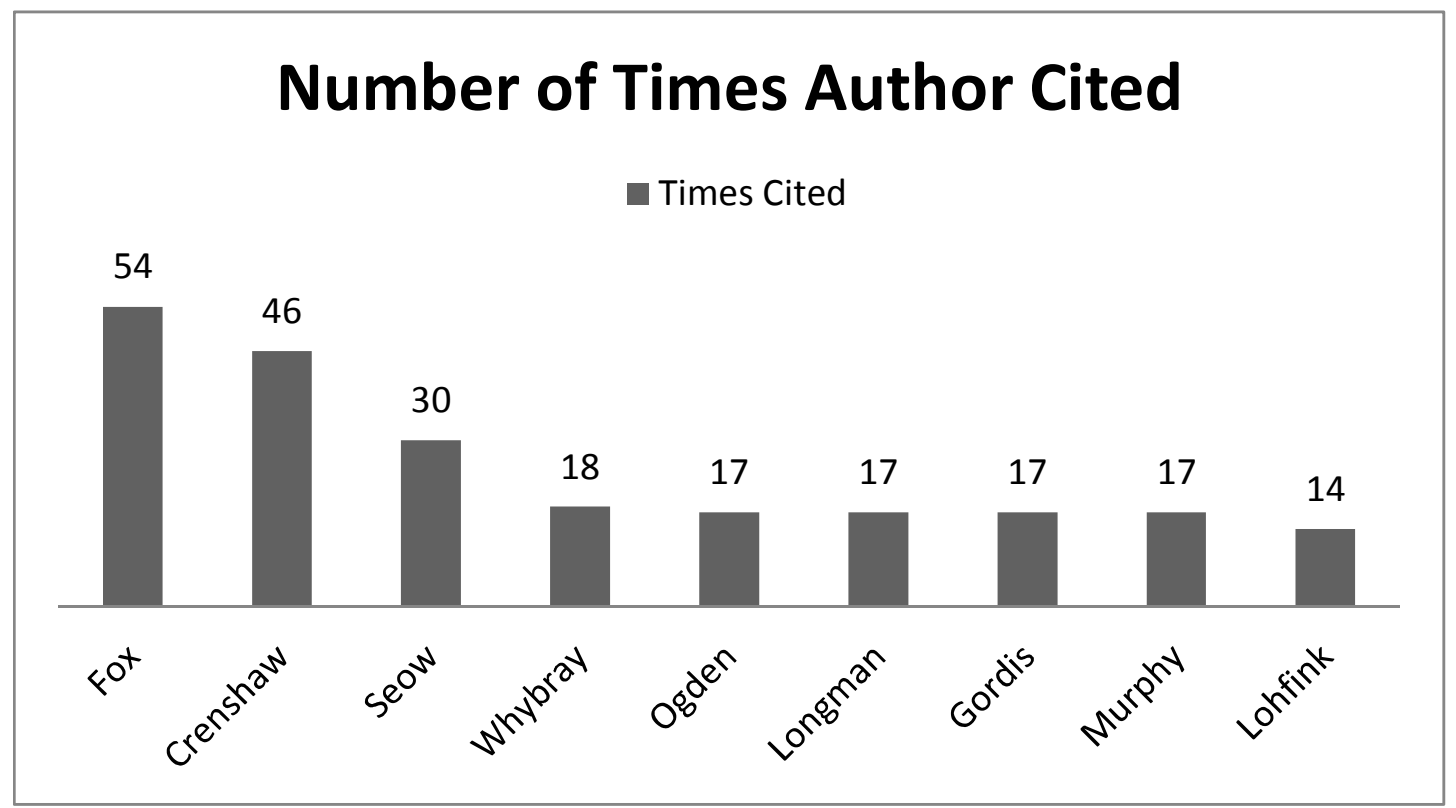

Figure 3: Number of Time Author Cited

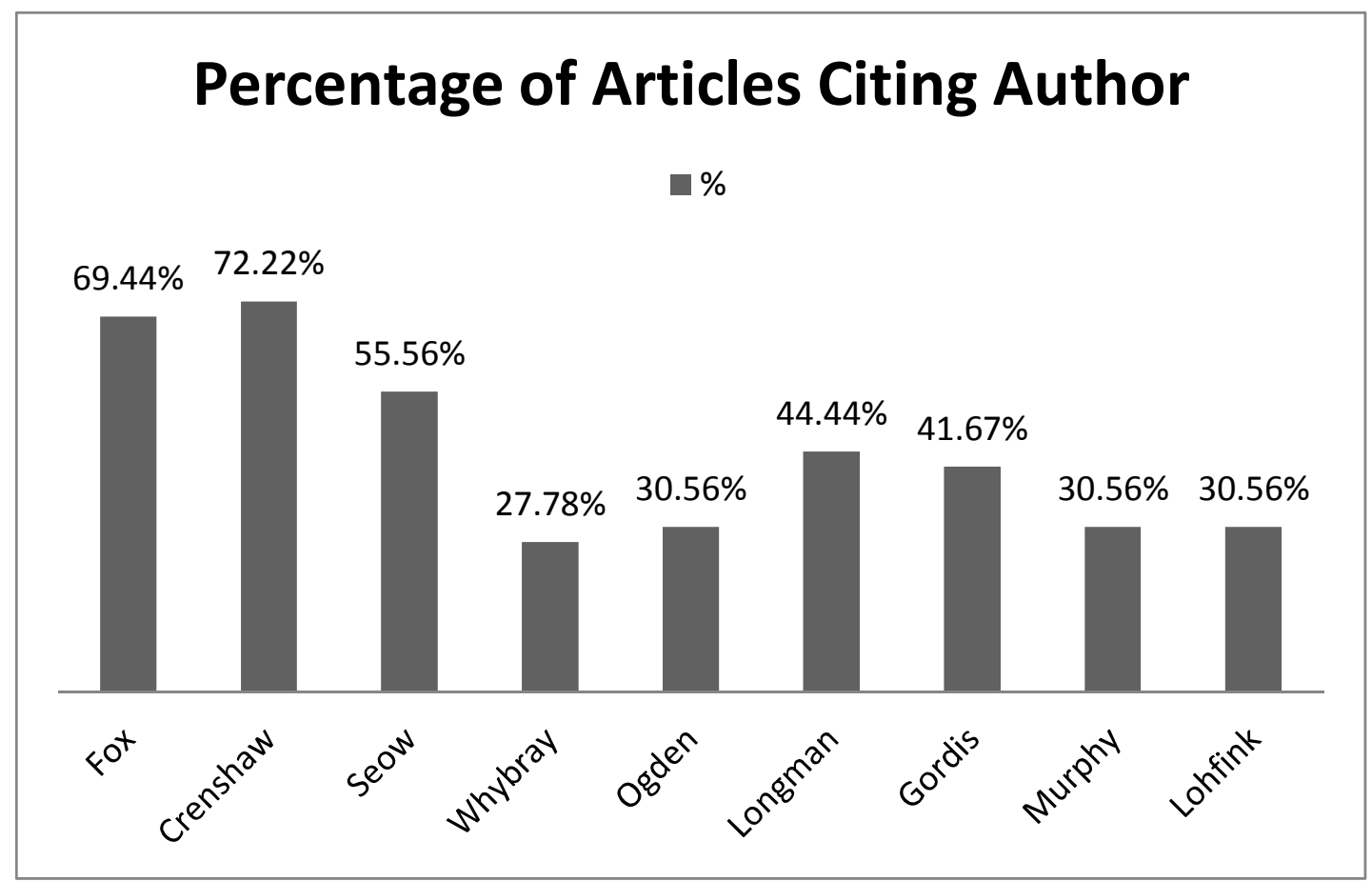

Figure 4: Percentage of Articles Citing Author 


\section{R3. Which journals are the most-cited in the articles in this study?}

As already noted, surprisingly less than $20 \%$ of the sources cited were articles from academic journals. According to the count, 85 different journals were cited. The Journal of Biblical Literature was cited 22 times. The Catholic Biblical Quarterly was cited 18 times. Vetus Testamentum was cited 17 times and the Journal for the Study of the Old Testament was cited 14 times. The Hebrew Union College Annual was cited 10 times. No other journal was cited more than 7 times.

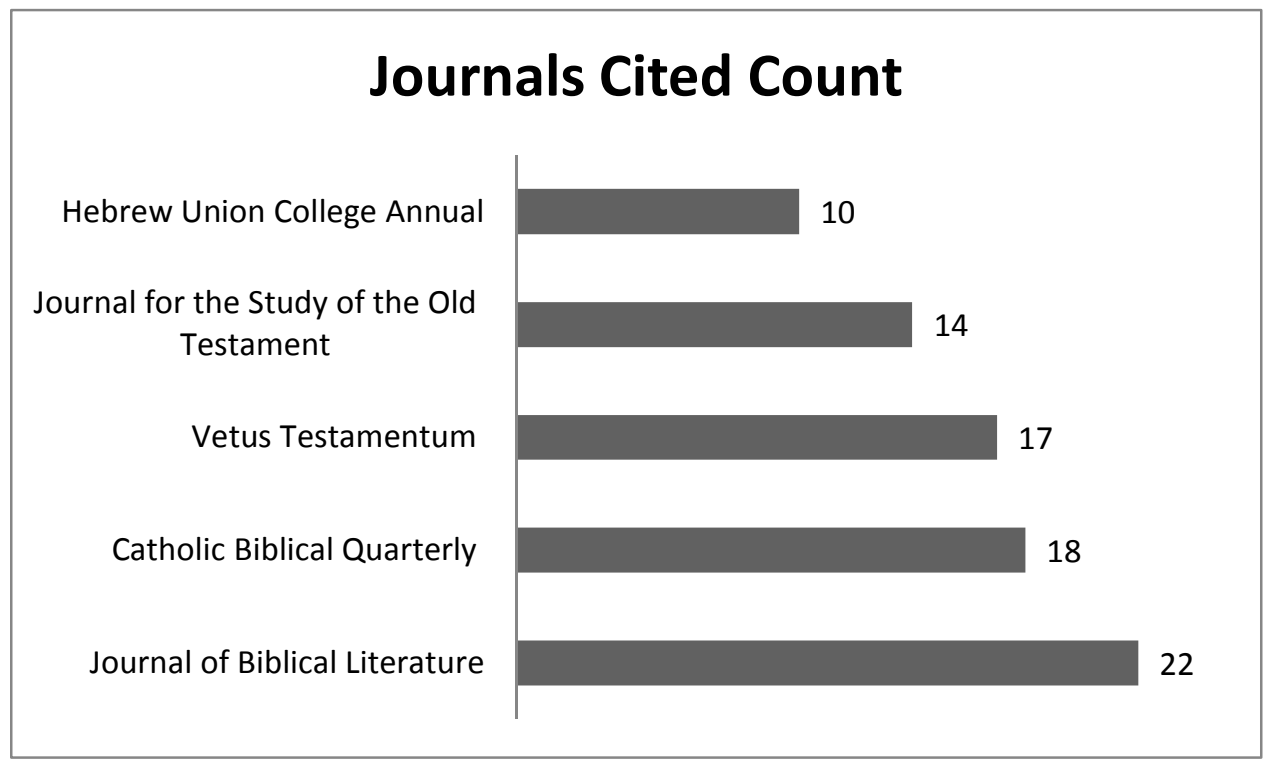

Figure 5: Journals Cited Count

Removing duplicated results (so that each article cited is counted only once regardless of the number of times it was cited in different articles) resulted in the Journal of Biblical Literature being counted 17 times, Vetus Testamentum being cited 14 times, the Journal for the Study of the Old Testament counted 12 times, the Catholic Biblical Quarterly 11 times, and the Hebrew Union College Annual 8 times. This suggests that while there was some duplication, no single article was cited a significant number of times. 


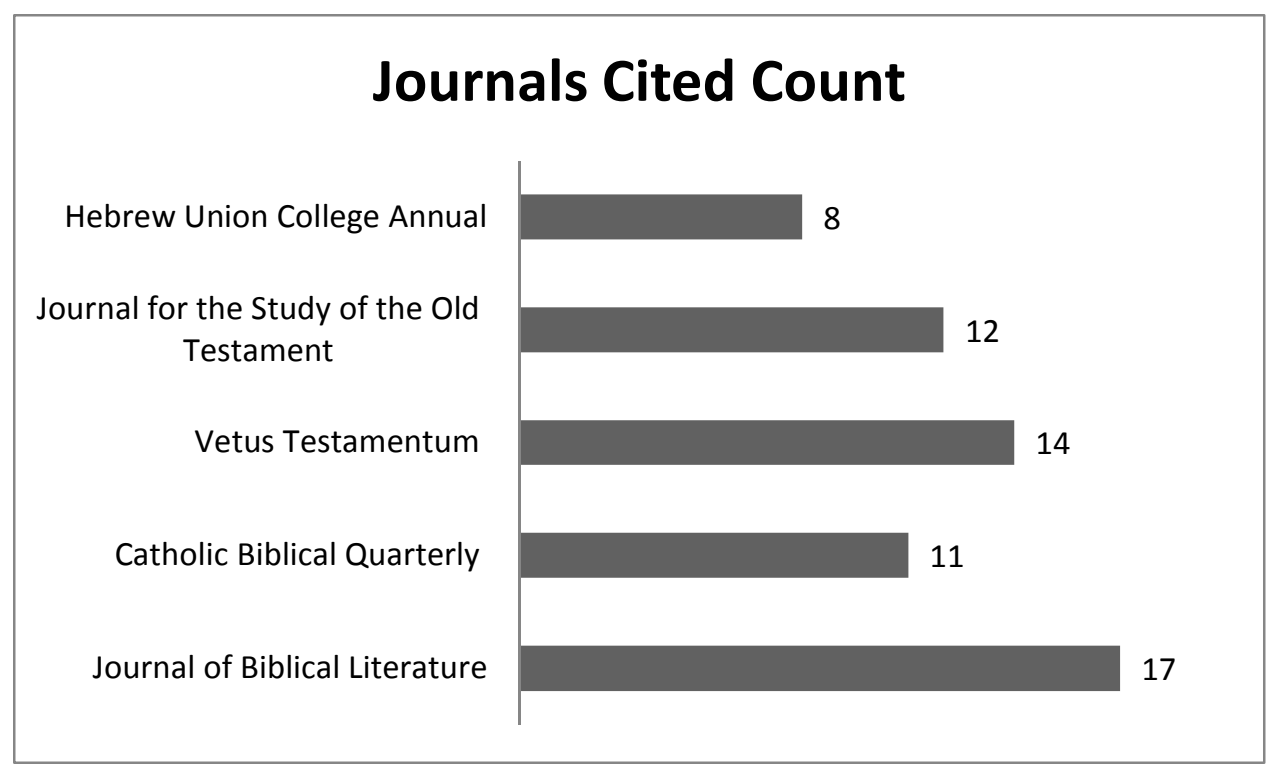

Figure 6: Journals Cited Count (Deduplicated)

\section{R4. What is the average age of the articles used in each article?}

As the data to answer the other questions were being collected, it became clear that even within such a narrow topic area as the biblical studies of Ecclesiastes, there were very different methods being used for using sources. One data stream that seemed to demonstrate this more than any others was the relative dating of the sources being used. For example, there was a variation of almost 55.7 years between the article that used the most recent sources (an average of 10.9 years for its 11 cited sources) and the one that had the oldest (an average of 66.6 years for its 27 sources). The average age of the sources used in all articles was 29.54 years. Removing Pinker's articles from the average dropped the average age to 24.55 years. Conversely Pinker's articles have an average of 53.65 years! 


\section{DISCUSSION}

\section{Review of Outcomes and Possible Implications}

Ultimately, each of the research questions was answered adequately. There can be little concern about the legitimacy of the data. There are some possible implications of the data that may potentially be significant. First, there is a common assumption that the major source for scholarly information for biblical studies is the scholarly journal article. In this particular data set this assumption was clearly called into question. With less than $20 \%$ of cited sources being scholarly journals it is significant that these articles built their own arguments on other data sources. It is possible that in biblical studies the pervasiveness of commentaries masks the importance of journal articles, but this is not clear. Furthermore, book sources (excluding commentaries) were used at a rate of over two for every one journal article used. For librarians this suggests that book sources continue to be an important part of research for scholars. Obviously this does not consider the medium used for book sources (ebook versus paper), but the librarian must be careful not to underestimate the need to maintain a good book collection in biblical studies.

A second implication develops when considering important scholars. Fully $20 \%$ of all citations (1134) in this study cited one of nine scholars. These scholars (Fox, Crenshaw, Murphy, Ogden, Longman, Whybray, Seow, Lohfink and Gordis) are without a doubt the most important in the field of Ecclesiastes studies, but the reliance on them is very informative. This suggests that it is possible that within the broader field of biblical studies, there are a handful of scholars that represent the largest share of authorities on a particular book of the Bible. The significance of this for librarians is that librarians (especially theological librarians or those who 
work with theology departments) must be aware of these scholars when doing collection development and helping with reference questions. A lack of awareness of this small group of scholars will severely limit a librarian's ability to help researchers as well as develop collections that adequately represent the scholarly field.

As already stated the number of journal citations was surprisingly low, however, the journals that were cited the most were not surprising at all. The Catholic Biblical Quarterly, the Journal for the Study of the Old Testament, the Journal of Biblical Literature, and Vetus Testamentum are all considered to be high quality journals in Hebrew Bible study.

Perhaps the biggest surprise was the age of the materials being used. Conventional wisdom says that scholarly work in biblical studies should use materials that are within about 25 years of their publishing date. While this was certainly the case if one factored out the Pinker articles, Pinker's articles should not be ignored. Two of Pinker's articles were in the journals listed above as being the most important in the field, thus, Pinker's work has been accepted as mainstream among his peers.

\section{Critique of the Study}

In many ways the study produced the results it set out to find. Perhaps the most important question that must be asked is whether the results really help to explain much. There is a danger in extrapolating the data to the study of other books in the Bible since each book of the Bible has its own set of variables. One critical question that needs to be answered is if ten years' worth of articles is a long enough time frame for establishing any patterns in a field of study that stretches centuries. 
One clear challenge for the study is the limitation of using the ATLA Religion Database as a guide for what articles would be included in the study. The fact that 10 of the 46 articles (21.7\% of the original total) had to be eliminated suggests that the indexing in the ATLA Religion Database may not be as precise as needed for this type of study. The researcher wonders how many articles that fit the criteria were not included because of other odd indexing in the ATLA Religion Database.

\section{Conclusions and Suggestions for Further Study}

Two conclusions seem warranted: The idea that monographs are losing importance in the electronic world of journals seems, at a minimum, to be overstated. Further verification of this conclusion needs to be done. Second, this study seems to support the idea that there is a small group of authoritative sources for the study of individual books of the Bible.

This leads to two areas of further study that need to be done. First, this type of study needs to be expanded within biblical studies. There seems to be an imperative for librarians to do this type of study to more strongly justify the purchase of not only journals, but commentaries and monographs in the theological library. Second, bibliometric studies would help to demonstrate the currency or lack of currency of biblical scholarship that is being done. It is the researcher's bias that often biblical scholars are guilty of using materials they are familiar with and ones that they know will already agree with their predetermined academic positions rather than the most current (and best) sources. Further bibliometric studies may be able to answer these questions. 


\section{ARTICLES USED FOR THE BIBLIOMETRIC STUDY}

Antic, R. (2006). Cain, Abel, Seth, and the meaning of human life as portrayed in the books of genesis and Ecclesiastes. Andrews University Seminary Studies, 44(2), 203-211.

Bøggild, J. (2012). The offensive retreat: An upbuilding discourse as a function of the paradox. Theology Today, 68(4), 424-437.

Carasik, M. (2003). Qohelet's twists and turns. Journal for the Study of the Old Testament, 28(2), 192-209.

Carasik, M. (2006). Transcending the boundary of death: Ecclesiastes through a Nabokovian lens. Biblical Interpretation, 14(5), 425-443.

Christianson, E., \& McWilliams, T. (2005). Voltaire's précis of Ecclesiastes: A case study in the Bible's afterlife. Journal for the Study of the Old Testament, 29(4), 455-484.

Crenshaw, J. L. (2007). Qoheleth in historical context. Biblica, 88(2), 285-299.

Curtis, E. M. (2005). Learning truth from sages. Christian Education Journal, 2(1), 113-128.

Dor-Shav, E. (2008). Ecclesiastes, fleeting and timeless: Part I. Jewish Bible Quarterly, 36(4), 211-221.

Dor-Shav, E. (2009). Ecclesiastes, fleeting and timeless: Part II. Jewish Bible Quarterly, 37(1), 17-23.

Drewes, B. F. (2005). Reading the bible in context: An Indonesian and a Mexican commentary on Ecclesiastes: Contextual interpretations. Exchange, 34(2), 120-133.

Fidler, R. (2006). Qoheleth in "the house of God": Text and intertext in Qoh 4:17-5:6 (Eng. 5:17). Hebrew Studies, 47, 7-21.

Fox, M. V. (2011). Ancient Near Eastern wisdom literature (didactic). Religion Compass, 5(1)

Gentry, P. J. (2006). The role of the "three" in the text history of the Septuagint': II. Aspects of interdependence of the Old Greek and the three in Ecclesiastes. Aramaic Studies, 4(2), 153-192.

Gómez Aranda, M. (2012). The influence of Isaac Ibn Ghayyat on Abraham Ibn Ezra's commentary on Ecclesiastes. Journal of Jewish Studies, 63(1), 84-104.

Greenwood, K. R. (2012). Debating wisdom: The role of voice in Ecclesiastes. Catholic Biblical Quarterly, 74(3), 476-491.

Helsel, P. B. (2010). Enjoyment and its discontents: Ecclesiastes in dialogue with Freud on the stewardship of joy. Journal of Religion and Health, 49(1), 105-117. 
Helsel, P. B. (2007). Warren Zevon's The Wind and Ecclesiastes: Searching for meaning at the threshold of death. Journal of Religion and Health, 46(2), 205-218.

Henze, M. (2008). Qoheleth and the Syriac Apocalypse of Baruch. Vetus Testamentum, 58(1), $28-43$.

Janzen, J. G. (2008). Qohelet on life "under the sun". Catholic Biblical Quarterly, 70(3), 465483.

Jarick, J. (2007). The enigma that is Ecclesiastes. Lutheran Theological Journal, 41(2), 103-109.

Jones, S. C. (2006). Qohelet's courtly wisdom: Ecclesiastes 8:1-9. Catholic Biblical Quarterly, 68(2), 211-228.

Klein-Braslavy, S. (2005). The Alexandrian prologue paradigm in Gersonides' writings. Jewish Quarterly Review, 95(2), 257-289.

Linafelt, T., \& Dobbs-Allsopp, F. (2010). Poetic line structure in Qoheleth 3:1. Vetus Testamentum, 60(2), 249-259.

Lo, A. (2008). Death in Qohelet. Journal of the Ancient Near Eastern Society, 31, 85-98.

Lyons, W. J. (2006). “Outing” Qoheleth: On the search for homosexuality in the wisdom tradition. Theology \& Sexuality, 12(2), 181-201.

Middlemas, J. A. (2007). Ecclesiastes gone "sideways". Expository Times, 118(5), 216-221.

Noegel, S. B. (2007). "Word play” in Qoheleth. Journal of Hebrew Scriptures, 7

Okello, J. B. O. (2004). Diffusing apparent biblical contradictions: A logical demonstration. Africa Journal of Evangelical Theology, 23(1), 47-60.

Pinker, A. (2008). Qohelet 4,13-16. SJOT, 22(2), 176-194.

Pinker, A. (2009). Qohelet 6:9 -- it looks better than it tastes. Journal of Jewish Studies, 60(2), 214-225.

Pinker, A. (2010). Experimenting with entertainment in Qohelet 2:1-3. Australian Biblical Review, 58, 17-35.

Pinker, A. (2011). The ligature $\square \mathrm{z}=\breve{\mathrm{s}}$ [hebrew characters] in qohelet 6.3. Bible Translator (Ja, Jl Technical Papers), 62(3), 151-164.

Pinker, A. (2011). The oppressed in Qohelet 4:1. Vetus Testamentum, 61(3), 393-405. 
Pinker, A. (2012). Qohelet 9:3b-7: A polemic against necromancy. Journal of Jewish Studies, 63(2), 218-237.

Polish, D. F. (2008). The Buddha as a lens for reading Koheleth/Ecclesiastes. Journal of Ecumenical Studies, 43(3), 370-382.

Reinhard, K. L. (2007). Passing sorrow, passing joy: Redefining wisdom in Qoheleth. Sewanee Theological Review, 51(1), 13-21.

Rosenberg, I. (2009). Koheleth and Goethe's Faust. Jewish Bible Quarterly, 37(2), 103-112.

Sanders, J. T. (2005). Wisdom, theodicy, death, and the evolution of intellectual traditions. Journal for the Study of Judaism in the Persian, Hellenistic and Roman Period, 36(3), 263-277.

Shuster, M. (2008). Being as breath, vapor as joy: Using Martin Heidegger to re-read the book of Ecclesiastes. Journal for the Study of the Old Testament, 33(2), 219-244.

Sneed, M. (2004). Qohelet and his 'vulgar' critics: A Jamesonian reading. Bible \& Critical Theory, 1(1)

Treier, D. J. (2008). A looser "canon"? Relating William Abraham's canon and criterion in Christian theology to biblical interpretation. Journal of Theological Interpretation, 2(1), 101-116.

Vogel, D. (2005). The legacy of two Adams. Jewish Bible Quarterly, 33(1), 3-12.

Whitwell, C. (2009). The variation of nature in Ecclesiastes 11. Journal for the Study of the Old Testament, 34(1), 81-97.

Wazana, N. (2007). A case of the evil eye: Qohelet 4:4-8. Journal of Biblical Literature, 126(4), 685-702.

Wernik, U. (2005). Will the real homosexual in the Bible please stand up? Theology \& Sexuality, $11(3), 47-64$.

Whitacre, R. A. (2007). Proverbs, Ecclesiastes, Song of Solomon. Anglican and Episcopal History, 76(2), 231-238. 


\section{WORKS CITED}

Ammerman, J. (2006). ATLA RDB: an environmental scan. American Theological Library Association Summary of Proceedings, 60, 169-173.

Ashman, A. B. (2009). An Examination of the Research Objectives of Recent Citation Analysis Studies. Collection Management, 34(2), 112-128.

Dahood, M. (1952). Language of Qoheleth. Catholic Biblical Quarterly, 14(3), 227-232.

Fox, M. V. (1999). A time to tear down and a time to build up: A rereading of Ecclesiastes. Grand Rapids: Eerdmans.

Hoffmann, K., \& Doucette, L. (2012). A Review of Citation Analysis Methodologies for Collection Management. College \& Research Libraries, 73(4), 321-335.

Knievel, J. E., \& Kellsey, C. (2005). Citation Analysis for Collection Development: A Comparative Study of Eight Humanities Fields. Library Quarterly, 75(2), 142-168.

Kellsey, C., \& Knievel, J. (2012). Overlap between Humanities Faculty Citation and Library Monograph Collections, 2004-2009. College \& Research Libraries, 73(6), 569-583.

Longman, T. (1998). The Book of Ecclesiastes. Grand Rapids: Eerdmans.

Murphy, R. E. (1992). Ecclesiastes. Dallas: Word Books.

Murphy, R. E. (2002). The tree of life: An exploration of biblical wisdom literature. Grand Rapids: Eerdmans.

Perry, T. A. (1993). Dialogues with Kohelet: The Book of Ecclesiastes. University Park: The Pennsylvania State University Press.

Rethlefsen, M. L. (2007). Citation analysis of Minnesota Department of Health official publications and journal articles: a needs assessment for the RN Barr Library. Journal of the Medical Library Association, 95(3), 260-266.

Seow, C. L. (1997). Ecclesiastes: A new translation with introduction and commentary. New York: Doubleday.

Smith, L. C. (1981). Citation analysis. Library Trends, 30(1), 83-106.

Society of Biblical Literature. (2011). About SBL. Retrieved from http://www.sblsite.org/aboutus.aspx 
Whybray, R. N. (1981) The identification and use of quotations in Ecclesiastes. In J. A. Emerton (ed.), Congress Volume (Vienna 1980) (pp. 435-451). Leiden: Brill.

Zhao, D., \& Strotmann, A. (2011). Counting First, Last, or All Authors in Citation Analysis: A Comprehensive Comparison in the Highly Collaborative Stem Cell Research Field. Journal Of The American Society For Information Science And Technology, 62(4), 654676. 